\title{
The value of Confucian culture on female college students' Entrepreneurship
}

\author{
Jie $\operatorname{Tian}^{1, a}$, Hou Mingdong ${ }^{2, b}$ \\ ${ }^{1}$ College of Information Technology, Shandong Womens University, Jinan, 250300 China \\ ${ }^{2}$ Department of Electrical and Automation, Shandong Labor Vocational and Technical College, \\ Jinan, 250300 China \\ atianjie918@163.com, bhmdcp@126.com
}

Keywords: Confucian culture; Female; Entrepreneurship

\begin{abstract}
To encourage contemporary college students' entrepreneurship under the background of the times, through the study of Confucianism and Confucian spirit, explore the Confucian spirit of excellent quality. At the same time, combined with the characteristics of female college students, to use Confucian spirit of the excellent quality of female college students in the beginning to establish a correct concept of entrepreneurship. While inheriting the traditional excellent culture quality of our country, through the combination of Confucian culture and entrepreneurship education, female college students can cultivate distinctive entrepreneurial ideas and ways, grasp core competitiveness and form an obvious competitive advantage with male college students.
\end{abstract}

\section{Introduction}

The nineteen main party of the Communist Party of China put forward "advocating the culture of innovation, strengthening the creation, protection and application of intellectual property rights." Training and training a large number of international level of strategic and technical personnel, science and technology leading personnel, young scientific and technological talents and high-level innovation team. After more than ten years of exploration and development, the entrepreneurship education in China has achieved remarkable results, faces some severe challenges. For example, the employment and entrepreneurship problems of female college students, many female college students influenced by the backward employment concept, poor initiative and weak innovation ability, which makes the employment and entrepreneurship problem worse.

Fortunately, entrepreneurship education in Colleges and universities can help female college students to get rid of the traditional concept of employment restraint and social public opinion and the environment pressure, leading the female students out of the plight of the lack of self-cognition, cultivate independent personality. Furthermore, recognize their own strengths and weaknesses, for female college students' employment is an effective way to provide the correct view. The challenge put forward from the aspects of measures for entrepreneurship education differentiation of female college students, to strengthen the female spirit through the infiltration of Confucian spirit, in order to cultivate entrepreneurship and entrepreneurial consciousness, is the ease of a powerful measure of female college students' employment pressure to drive employment.

\section{The main challenges facing female college students in Entrepreneurship Education in China}

Entrepreneurship education is a systematic and complex project, it is not the "behind closed doors" is able to accomplish. It needs to learn from the experience of foreign enterprise education for a long time, as well as the actual situation of the education group and the early stage of entrepreneurship education in China. Therefore, we should conform to the local culture, take the school as the main position of entrepreneurship education and set up the supporting system of government and society. So as to promote the all-round development of entrepreneurship education. 


\section{Challenges faced by gender based employment in society}

Since the enrollment expansion of colleges and universities, the number of college students has increased sharply. The proportion of female college students has increased year by year, and the number of girls in many liberal arts and normal universities has been dominant. However, in the field of employment, the employment opportunities and the quality of employment of female college students are far lower than those of male students. Under the same conditions, the employers tend to choose male college students first. According to the theory of social gender, the reason for male students can take the dominant position in the job market and even get the social status higher than their ability, which is the expression of social gender mark determined by traditional culture. The exclusion and unfair treatment of female college students in the process of employment are also social discrimination caused by social and cultural factors[1].

\section{Challenge of the difference of entrepreneurship education}

Educational equity is not a simple equality, on the contrary, the existence of educational differences should be allowed. The differences in various regions exist, so it is impossible to realize the equality of educational resources between the absolute regions. The differences between students exist, so it is unscientific to face the students' collective with equal educational means. The use of different ways for different students to fully display is the practice of the principle of difference in the theory of educational equity. From the start in current higher education, although the male and female college students have equal opportunities for entrepreneurship education, but the current entrepreneurship education mode in Colleges and universities are more drawn from the male standard, female students in which it is difficult to play its own characteristics and advantages, the path of entrepreneurship has become particularly difficult[2]. Therefore, in the process of entrepreneurship education in Colleges and universities, we should pay attention to following the gender advantages and characteristics of female college students, carry out entrepreneurship education activities suitable for female college students, mobilize their enthusiasm and enhance their comprehensive competitiveness in employment.

\section{Challenges posed by the impact of gender culture}

"Gender culture" often exerts a subtle influence on people's minds, the stereotype of gender culture consists of two levels of sex and social gender, which endow healthy, tall, thick, bold, sloppy heart etc., whereas women are gentle, gentle curve as the incarnation, but cautious, timid and emotional image[3-4]. When it comes to entrepreneurship, most people think that male is the main reason. The inherent idea of this society makes many female college students dare not touch on entrepreneurship and even exclude entrepreneurship education[5-6]. However, in our real life, a typical female entrepreneurial success of innovative new women meet the eye everywhere, the job market is beyond count so for entrepreneurship education, we should also look to the perspective of development, break the shackles of physiological determinism, attach importance to and strengthen the entrepreneurship education for female college students.

\section{Confucian culture in cultivating college students' entrepreneurial spirit value}

\section{The benefit of cultivate the strong sense of social responsibility for female college students' entrepreneurs}

Review of Chinese history, numerous large business critical moment in the country and the nation's best wealth through to save the country and the people and between fire and water. In view of the current student entrepreneurial activities, although most of the motives of college students are different, most entrepreneurs start from their own interests and do not realize their social value. Although Confucianism is to obtain benefits as the first objective, but is highly Confucian business standing in the maintenance of social policy order, helping people, they strengthen management standards, meaning that the profit after the first, the height of the thought determines the life cause height. The same is true of College Students' entrepreneurs, and their entrepreneurial spirit is highly determined by the height of the development of the enterprise. Therefore, to strengthen the female 
college student entrepreneurs Confucian culture, to promote female college students' entrepreneurial social responsibility is not necessarily a useful attempt.

\section{Confucian culture is beneficial to the female college students' team cooperation consciousness}

With Confucian culture on female college students' entrepreneurship education, the purpose is not to let all students to entrepreneurship, but to develop the employment concept and the idea of female college students better, can be integrated into the work better in the future. Confucian culture is a kind of exquisite "honesty" and "mean" and "benevolence", "Li" and "Master" and "win-win" philosophy. The enterprise not only need good leaders, also need the talent level to hard-working attitude, talent, need to be able to create the benefit and value for the enterprise talent, need and enterprise development, talent symbiosis of one heart and one mind together. Compared to male character, most of the girls thought character are more likely to receive the community standard of Confucian culture. On the one hand, the Confucian culture and the Confucian spirit inheritance to change the female college students' employment, enhance the initiative and innovation ability[7-8]. On the other hand teach entrepreneurship education knowledge and skills, mining of female college students' entrepreneurial potential, the more female students from the demands of the job into a job supply and creators. If the Confucian culture instilled in the society is the inevitable development of female college students, contribute to the work of enterprise management and enterprise culture construction.

\section{Confucian culture is conducive to self-consciousness shaping of female college students}

Is the so-called: "heaven, the gentleman to unremitting self-improvement; terrain Kun, the gentleman to social commitment". The Confucian spirit advocated the spirit of unremitting self-improvement spirit and fighting spirit of the modern market economy is the complement. The Confucian culture transformation of female college students in the traditional concept of employment, change from passive to active, improve the ability of innovation. Through the combination of Confucian culture and entrepreneurship education, female college students can cultivate distinctive entrepreneurial ideas and ways, grasp core competitiveness and form an obvious competitive advantage with male college students. To help female college students change their concept of employment, establish a correct view of employment, the new female college students are lack of self-confidence, independence, initiative and poor employment mentality, lack of entrepreneurial spirit and consciousness, is not good at independent choice, not good at planning their own occupation career. Compared with men, has certain advantages, the expression of female college students in the language writing, image thinking, interpersonal communication and thinking style, work attitude, attention degree, especially in planning, communication, coordination and other aspects, only slightly in innovative problems. Entrepreneurship Education in Colleges and universities can help female college students to get rid of the traditional concept of employment restraint and social public opinion and the environment pressure. Which leading the female students out of the plight of the lack of self-cognition, cultivate independent personality, and recognize their own strengths and weaknesses, for female college students' employment is an effective way to provide the correct view.

The Confucian culture enriched the theory of entrepreneurship education, the development of social gender theory, introducing the hierarchical classification of educational thoughts

Entrepreneurship education is an educational model promoted and developed under the background of great economic and social development, college students' employment and reemployment. Put forward "entrepreneurship education" theory [9-10], not only enrich the University of College Students' employment guidance education theory, a new way of research and education theory research and practice reform and. In recent years, although many colleges and universities have carried out the work of College Students' entrepreneurship education, there are few individualized entrepreneurship education for female college students. Therefore, paying attention to strengthening the entrepreneurship education of female college students and carrying out the theoretical and empirical research of entrepreneurship education for female college students will greatly enrich the theory of entrepreneurship education in universities and expand the function of higher education. 
Based on the recognition of the physiological differences between men and women, the social gender theory holds that social culture has a certain impact on gender differences. Social gender differences are not created by realized through social and cultural influences. At the same time, the theory holds that higher education, which is equal and different, is the necessary requirement for women to get a real right to equality with men. In China, women accounted for $48.73 \%$ of the total population of female college students. Accounting for $49.68 \%$ of the number of undergraduate colleges and universities, it is an important part of social human resources. Although our country's higher education has been the implementation of non-discriminatory education, but many aspects of education have been the dominant or recessive existence of a gender prejudice and discrimination, the growth and development of women constitute a direct or potential resistance, and ultimately hinder the realization of real education fair. Therefore, a gender perspective throughout the process of the implementation of entrepreneurship education in the face of gender differences between men and women with "both physical and mental characteristics of female students, this has both commonness and individuality of the entrepreneurship education for female students can give full play to their own advantages. Reshaping the college female student's social role and status, but also helps to achieve the equality between men and women, rich and more help to the development of social gender theory. The educational idea of stratified classification introduce in the process of entrepreneurship education. The aim is to take different forms of entrepreneurship education in accordance with the individual differences of female students. To participate in the campus entrepreneurship practice of female college students, entrepreneurship education can obtain entrepreneurial knowledge and entrepreneurial ability training. Access to business opportunities to practice, to lay a solid foundation for the future path of entrepreneurship; and for the general non-entrepreneurial intention of university women, through entrepreneurship education can cultivate awareness of entrepreneurship and entrepreneurial spirit, the ability to play with the character of female college students, enhance the core competitiveness of employment. Besides, for different disciplines of female college students, entrepreneurship education should have differentiated characteristics. According to the characteristics and characteristics of different disciplines and specialties, we should choose suitable entrepreneurship education mode.

\section{Conclusion}

Nowadays, China in rapid integration into the global economic integration background, Confucian culture is to cooperate with the world civilization and civilization dialogue Chinese platform. Confucian wisdom in the economic globalization today, there is still no substitute for the modern value of Confucian culture is not only outdated, some ideas and ethics of globalization which echoes. Therefore, it is of positive and realistic significance to combine the Confucian culture with the innovative and entrepreneurial education of female college students. If you follow the "checklist" your paper will conform to the requirements of the publisher and facilitate a problem-free publication process.

\section{Acknowledgment}

This work was supported in Support at Key subjects of Art Science in Shandong (ZD:20161006), College of Information Technology, Shandong Women's University, China.

\section{References}

[1] Ma Jinhe. Contemporary college students from the traditional culture of social discrimination in employment. China Youth Study,10(2013),88 91(in Chinese)

[2] Yanwei, Chen Changhuai, Chenyan. The threshold value of consistency index for analytic hierarchy. Journal of Applied Statistics and Management,3(2011):417 423(in Chinese) 
[3] Karamouz M, Zahraie B, Reza K. Developing a master plan for hospital solid waste management: A case study[J]. Waste Management, 2007, 27(5): 626-638.

[4] The Comparison between the Undergraduates' Gender Role of China and America and It's Inspi ration .Journal of higher education 2014,35(1):68-75(in Chinese)

[5] Stein W E,and Mizzi P J. The harmonic consistency index for the analysis hierachy process [J]. European Journal of Operational Research,2007,177:488-497

[6] Watts,A.G.\&Van Esbroek, NEW Skills for New Futures: Higher Education Guidance and Couselling Services in the European Union.Brussels, VUB Press,1998.

[7] Hillage,J,\& Pollard , Employability; Developing a Framework for Policy Analysis, DFEE Research Report,1998.

[8] Harry N. Drier. Special Issue Introduction: Career and Life Planning Key Feature With Comprehensive Guidance Programs [J]. Journal of Career Development, 2007(2):73-80

[9] Carsrud, A. ,Brnnback,M. Entrepreneurial Motivations :what do we still need to know? [J].Journal of Small Business Management ,2011,49(1):9-26.

[10]Paul D. Reynolds ,S. Michael Camp ,William D.Bygrave ,Erkko Autio, Michael Hay.GEM 2001 Global Report[R].Babson College ,2001:4. 